\title{
3': 5'-Cyclic Nucleotide Phosphodiesterase of Mycobacterium smegmatis
}

\author{
By C. H. LEE* \\ Department of Clinical Biochemistry, University of Otago, \\ Medical School, Dunedin, New Zealand
}

(Received 24 January 1978)

\section{INTRODUCTION}

The intracellular concentration of adenosine $3^{\prime}: 5^{\prime}$-cyclic monophosphate (cyclic AMP) at any given instant depends on the relative activities of adenylate cyclase and phosphodiesterase, the latter enzyme being known to break down cyclic AMP to AMP in mammalian and bacterial systems (Robison, Butcher \& Sutherland, 1971). The elucidation of the properties of the phosphodiesterase in $M$. smegmatis provides a sound basis for further investigations on the role of cyclic AMP in the regulation of mycobacterial cell function.

\section{METHODS}

Culture and harvest of micro-organisms. Mycobacterium smegmatis NCTC 523 has been maintained in our aboratory since 1966 . Cultures were maintained without shaking at $37^{\circ} \mathrm{C}$ in $25 \mathrm{ml}$ synthetic medium in $100 \mathrm{ml}$ conical flasks and subcultured every $4 \mathrm{~d}$. The bacteria grew as a thick creamy surface pellicle. The synthetic growth medium (Clark, 1971) contained (per litre distilled water): L-asparagine. $\mathrm{H}_{2} \mathrm{O}, 4 \mathrm{~g}$; citric acid. $\mathrm{H}_{2} \mathrm{O}$, $2 \mathrm{~g}$; glycerol, $30 \mathrm{~g}$; $\mathrm{MgSO}_{4} .7 \mathrm{H}_{2} \mathrm{O}, 0.5 \mathrm{~g}$; thiamin, $10 \mathrm{mg} ; \mathrm{KH}_{2} \mathrm{PO}_{4}, 0.5 \mathrm{~g}$; ammonium ferric citrate, $50 \mathrm{mg}$; inorganic salt solution, $1 \mathrm{ml}$; DL-lactic acid solution (about $85 \%$, w/w; boiled and neutralized), $10 \mathrm{~g}$. The pH was adjusted to $7 \cdot 2$ with solid $\mathrm{NaOH}$. The inorganic salt solution contained (per litre): ammonium molybdate. $4 \mathrm{H}_{2} \mathrm{O}, 64 \mathrm{mg}$; $\mathrm{ZnSO}_{4} \cdot 7 \mathrm{H}_{2} \mathrm{O}, 2 \mathrm{~g}$; and $\mathrm{MnCl}_{2} .4 \mathrm{H}_{2} \mathrm{O}, 45 \mathrm{mg}$.

For large scale growth, bacteria were grown for $3.5 \mathrm{~d}$ in Roux flasks each containing $200 \mathrm{ml}$ growth medium and harvested by decanting the medium and filtering through three layers of muslin. The harvested bacteria were washed three times with distilled water, packed by centrifuging and stored at $-80^{\circ} \mathrm{C}$.

Preparation of extracts. Frozen bacteria were thawed, suspended in $60 \mathrm{~mm}-\mathrm{Tr}$ is/ $\mathrm{HCl}$ buffer (pH 8.0 or $9 \cdot 0$ ) and sonicated in a $100 \mathrm{~W}$ ultrasonic disintegrator (MSE) for $20 \mathrm{~min}$ at $0{ }^{\circ} \mathrm{C}$. The disrupted cells were centrifuged at $39100 \mathrm{~g}$ for $40 \mathrm{~min}$ at $4{ }^{\circ} \mathrm{C}$. The pellet was discarded and the supernatant was kept at $-80^{\circ} \mathrm{C}$. The enzyme was stable for at least 1 month at this temperature. Enzyme dilution was carried out with $0 \cdot 1 \%(\mathrm{w} / \mathrm{v})$ albumin. Protein was determined by the method of Lowry et al. (1951).

Assay of phosphodiesterase (3': 5'-cyclic-AMP 5'-nucleotidohydrolase; EC 3.1.4.17). This assay was based on the hydrolysis of cyclic AMP to AMP by phosphodiesterase and subsequent conversion of the AMP to adenosine by the nucleotidase of Crotalus atrox venom (Sigma) as described by Loten \& Sneyd (1970). The assay mixture (total volume $50 \mu \mathrm{l}$ ) contained: $2.5 \mu \mathrm{mol} 0.05 \mathrm{M}$-Tris $/ \mathrm{HCl}$ buffer, $\mathrm{pH} 8.0$ (or 9.0), $0.5 \mu \mathrm{mol}$ $\mathrm{MgSO}_{4}$, cyclic [ ${ }^{3} \mathrm{H}$ ]AMP (about 30000 c.p.m.), cyclic AMP (various concentrations) and enzyme preparation. The mixture was incubated at $37{ }^{\circ} \mathrm{C}$ for $10 \mathrm{~min}$. Snake venom $\left(20 \mu 1,7.2 \mathrm{mg} \mathrm{ml}^{-1}\right.$ in $60 \mathrm{~mm}$-Tris/ $\mathrm{HCl}$ buffer, $\mathrm{pH} 8.0$ ) was then added and the mixture was incubated for a further $10 \mathrm{~min}$. The reaction was stopped by adding $50 \mu \mathrm{l} 5 \mathrm{~mm}$-adenosine in $50 \mathrm{~mm}$-EDTA ( $\mathrm{pH} \mathrm{4.6)}$ ) and the tube was immediately transferred to an ice bath. Samples could be kept in an ice bath for at least $3 \mathrm{~h}$ without any change in the amount of $\left[{ }^{3} \mathrm{H}\right] \mathrm{adeno}-$ sine present. EDTA was inhibitory to the enzyme (see Results). The [ $\left.{ }^{3} \mathrm{H}\right]$ adenosine was separated from unchanged cyclic $\left[{ }^{3} \mathrm{H}\right] \mathrm{AMP}$ using a column $(25 \times 5 \mathrm{~mm})$ of anion exchange resin (Bio-Rad AG1-X2, 200 to 400 mesh). Samples were washed through with $3 \mathrm{ml}$ water which eluted adenosine. Recovery of adenosine from columns (calculated from the absorbance at $260 \mathrm{~nm}$ ) was usually better than $96 \%$. Radioactive adenosine was determined by counting a sample $(1.0 \mathrm{ml})$ in $10 \mathrm{ml}$ dioxan-based scintillation fluid.

A modified version of this assay was used in some experiments. Phosphodiesterase activity was stopped by

* Present address: Department of Biochemistry and Microbiology, University of Agriculture Malaysia, Serdang, Selangor, Malaysia. 
adding $50 \mu 150 \mathrm{~mm}$-EDTA and heating at $100^{\circ} \mathrm{C}$ for $2 \mathrm{~min}$. The mixture was brought to $37^{\circ} \mathrm{C}, 20 \mu 1$ snake venom $\left(7.2 \mathrm{mg} \mathrm{ml}^{-1}\right.$ in $60 \mathrm{~mm}$-Tris/ $\mathrm{HCl}$ buffer, $\left.\mathrm{pH} 8.0\right)$ was added and the mixture was incubated for $10 \mathrm{~min}$. The action of snake venom was stopped by heating in a boiling water bath for 2 min after adding $50 \mu 15 \mathrm{~mm}$-adenosine solution. The tube was cooled and $1 \mathrm{ml}$ of a $50 \%(\mathrm{w} / \mathrm{v})$ suspension of anion exchange resin (AG1-X2, 200 to 400 mesh) was added; the mixture was shaken and allowed to equilibrate for $10 \mathrm{~min}$ before centrifuging to sediment the resin. Radioactive adenosine remained in the supernatant. A sample of the supernatant (usually $400 \mu \mathrm{l}$ ) was added to $10 \mathrm{ml}$ dioxan-based scintillation fluid for radioactivity determinations. Less than $9 \%$ of the substrate was utilized in both assays. Under these conditions, formation of $\left.{ }^{3} \mathrm{H}\right] \mathrm{adenosine}$ was linear with time and enzyme concentration.

For experiments involving the effect of cations (used as chlorides) on phosphodiesterase activity, the enzyme preparation was first passed through a Sephadex G-25 column $(25 \times 110 \mathrm{~mm})$ equilibrated with $0.25 \mathrm{M}$-Tris/ $\mathrm{HCl}$ buffer ( $\mathrm{pH} \mathrm{9.0)}$ to remove low molecular weight compounds. The various cations did not affect the second stage of the two-step assay.

Inorganic phosphate and pyrophosphate interfered with the two-stage assay method. When these compounds were present, AMP formed in the reaction was separated from cyclic AMP and other products by paper chromatography. The assay mixture (total volume $40 \mu$ l) contained: $2.5 \mu \mathrm{mol} 0.06 \mathrm{M}$-Tris $/ \mathrm{HCl}$ buffer (pH 9.0), $\mathrm{Mg}^{2+}$ (various concentrations), $0.005 \mu \mathrm{mol}$ cyclic AMP, cyclic [ $\left.{ }^{3} \mathrm{H}\right] \mathrm{AMP}$ (about 40000 to 50000 c.p.m.), inorganic phosphate or pyrophosphate and enzyme preparation. The mixture was incubated at $37^{\circ} \mathrm{C}$ for $35 \mathrm{~min}$. Formation of AMP was linear with time and enzyme concentration. No $5^{\prime}$-mononucleotidase activity was detectable under these assay conditions. The reaction was stopped by adding $5 \mu 150 \%(\mathrm{w} / \mathrm{v})$ trichloroacetic acid. After centrifuging, $35 \mu 1$ of the supernatant was spotted on Whatman no. 1 paper and developed with 2-propanol/14.8 M ammonia/water (7:1:2, by vol.). The AMP spots (clearly separated from cyclic AMP) were detected under ultraviolet light (about $254 \mathrm{~nm}$ ), cut out and counted in $10 \mathrm{ml}$ toluene scintillation fluid.

To show that AMP was the only product formed in the reaction, a sample of the reaction mixture was spotted on cellulose thin-layer plates. Thin-layer chromatograms developed in solvent systems (i) isobutyric acid/0.5 M-ammonium hydroxide (5:3, by vol.), (ii) 2-propanol/ammonia/water $(7: 1: 2$, by vol.), (iii) 1-butanol/acetone/acetic acid/14.8 M-ammonia/water (90:30:20:1:60, by vol.), (iv) 1-butanol/acetic acid/water (5:2:3, by vol.) and (v) tert-butyl alcohol/11 $\mathrm{M}-\mathrm{HCl} /$ water $(70: 13 \cdot 2: 16 \cdot 8$, by vol.) showed that AMP was the only product.

Liquid scintillation counting. Radioactivity of all samples was determined in a Packard model 3375 scintillation spectrometer. Materials for liquid scintillation counting were obtained from Packard Instrument Co. (Downers Grove, Illinois, U.S.A.). Dioxan-based scintillation fluid contained: naphthalene, $62.5 \mathrm{~g} ; 2$,5diphenyloxazole (PPO), $3.75 \mathrm{~g}$; 1,4-di-(2-methylstyryl)benzene, 0.19 g; 1,4-dioxan, $500 \mathrm{ml}$. Toluene scintillation fluid contained: PPO, $4 \mathrm{~g} ; 1$,4-di-2-(5-phenyloxazolyl)benzene, $0.05 \mathrm{~g}$; sulphur-free toluene to make 1 litre. Cyclic [ ${ }^{3} \mathrm{H}$ ]AMP $\left(6.5\right.$ or $\left.14.2 \mathrm{Ci} \mathrm{mmol}^{-1}\right)$ was supplied by The Radiochemical Centre, Amersham, and was purified before use by passage through a column of ion exchange resin (AG1-X2, 200 to 400 mesh, chloride form).

\section{RESULTS}

Determination of $K_{\mathrm{m}}$. The range of values obtained for the $K_{\mathrm{m}}$ of the phosphodiesterase was 57 to $66 \mu \mathrm{M}$.

Effect of temperature on enzyme activity. Enzyme activity was measured at various temperatures between 20 and $60{ }^{\circ} \mathrm{C}$. The temperature for maximum phosphodiesterase activity was $55{ }^{\circ} \mathrm{C}$. The activity was $45 \%$ of the maximum at $37{ }^{\circ} \mathrm{C}$ and the enzyme was completely inactive at $20^{\circ} \mathrm{C}$. The enzyme was reasonably heat-stable. After $10 \mathrm{~min}$ at $55{ }^{\circ} \mathrm{C}$, approximately $80 \%$ of its original activity remained. Less than $10 \%$ of its original activity remained after $10 \mathrm{~min}$ at $70^{\circ} \mathrm{C}$. The enzyme was stable at $37^{\circ} \mathrm{C}$ or at room temperature for at least $24 \mathrm{~h}$.

Effect of $p H$. The phosphodiesterase of $M$. smegmatis exhibited its optimum activity in the alkaline range, with highest activity at $\mathrm{pH} 9 \cdot 0$. At $\mathrm{pH} 7 \cdot 0$, only $37 \%$ of its maximum activity was observed.

Effect of cations. The optimum concentrations of various metal ions producing maximum phosphodiesterase activity in $M$. smegmatis are shown in Table 1 . The most stimulatory metal ion was $\mathrm{Mg}^{2+}$. All the metal ions tested had their maximum effect on phosphodiesterase activity at concentrations below about $0.05 \mathrm{~mm}$ with the exception of $\mathrm{Mg}^{2+}, \mathrm{Ba}^{2+}$ and $\mathrm{Co}^{2+}$. In general, monovalent cations caused only a small stimulation in phospho- 
Table 1. Effect of cations at their optimum concentrations on phosphodiesterase activity'

Activity was assayed by the modified procedure described in Methods. Phosphodiesterase activity in the absence of added cation (taken as $100 \%$ ) was $95.9 \mathrm{pmol}$ adenosine present in $400 \mu \mathrm{l}$ supernatant (see Methods).

$\begin{array}{lcc}\text { Cation } & \begin{array}{c}\text { Optimum } \\ \text { concn (mM) }\end{array} & \begin{array}{c}\text { Relative } \\ \text { activity }\end{array} \\ \mathrm{Mg}^{2+} & 2 \cdot 5 & 202 \\ \mathrm{Ni}^{2+} & 0 \cdot 05 & 182 \\ \mathrm{Co}^{2+} & 1 \cdot 0 & 176 \\ \mathrm{Ca}^{2+} & 0 \cdot 025 & 173 \\ \mathrm{Al}^{3+} & 0 \cdot 025 & 159 \\ \mathrm{Fe}^{3+} & 0 \cdot 25 & 157 \\ \mathrm{Ba}^{2+} & 5 \cdot 0 & 148 \\ \mathrm{Mn}^{2+} & 0 \cdot 063 & 141 \\ \mathrm{Cd}^{2+} & 0.025 & 140 \\ \mathrm{Fe}^{2+} & 0 \cdot 25 & 140 \\ \mathrm{Cs}^{+} & 0.025 & 136 \\ \mathrm{~K}^{+} & 0 \cdot 25 & 133 \\ \mathrm{Na}^{+} & 0.05 & 132 \\ \mathrm{Cu}^{2+} & 0.05 & 125 \\ \mathrm{NH}_{4}^{+} & 0.05 & 119\end{array}$

diesterase activity. Of the four ions tested, $\mathrm{Cs}^{+}$was the most stimulatory and $\mathrm{NH}_{4}{ }^{+}$the least.

All divalent metal ions tested stimulated phosphodiesterase activity. However, unlike other divalent cations, $\mathrm{Cd}^{2+}$ was inhibitory at concentrations greater than $0.2 \mathrm{~mm}$ while $\mathrm{Cu}^{2+}$ was only slightly active at its optimum concentration and inhibitory at concentrations above $0.27 \mathrm{~mm}$.

Only two trivalent metal ions were tested. $\mathrm{Al}^{3+}$ was slightly more potent in stimulating phosphodiesterase activity than $\mathrm{Fe}^{3+}$. Neither ion was inhibitory at concentrations up to $1.0 \mathrm{~mm}$.

Effect of compounds known to affect mammalian phosphodiesterase. Caffeine and theophylline at concentrations up to $30 \mathrm{~mm}$ had no effect on the $M$. smegmatis enzyme. Pyrophosphate and inorganic phosphate $(2.0 \mathrm{~mm})$ stimulated the enzyme by $51 \%$ and $25 \%$, respectively, while EDTA ( $25 \mathrm{~mm}$ ) inhibited the enzyme by $98 \%$.

\section{DISCUSSION}

In $M$. smegmatis, repeated experiments showed that only one form of phosphodiesterase able to hydrolyse cyclic AMP was present. The presence of a low $K_{\mathrm{m}}$ enzyme $\left(K_{\mathrm{m}}\right.$ less than $10 \mu \mathrm{M})$ could not be demonstrated in cell-free extracts. The $K_{\mathrm{m}}$ of the enzyme was similar to that of Chlamydomonas reinhardii (Fischer \& Amrhein, 1974), but lower than those of other micro-organisms including Saccharomyces carlsbergensis (Speziali \& van Wijk, 1971), Saccharomyces cerevisiae (Fujimoto, Ichikawa \& Tomita, 1974), Serratia marcescens (Okabayashi \& Ide, 1970a), Brevibacterium liquefaciens and Escherichia coli (Okabayashi \& Ide, $1970 \mathrm{~b}$ ). The enzyme was more heat-stable than those of mammalian origin (Song \& Cheung, 1971).

The enzyme from $M$. smegmatis exhibited maximum activity at pH 9.0. Maximum phosphodiesterase activity in animal tissues (Nair, 1966) and unicellular organisms (Speziali \& van Wijk, 1971; Chang, 1968; Okabayashi \& Ide, 1970 ; Fujimoto et al., 1974; David, 1977) generally occurs in the alkaline range. Cheung (1971) has pointed out that the optimum $\mathrm{pH}$ for phosphodiesterase activity can vary with the exogenous ions added. The values mentioned above were determined in the presence of $\mathrm{Mg}^{2+}$.

The effect of various metal ions on phosphodiesterase activity has been studied in animal 
tissues (Song \& Cheung, 1971) and micro-organisms but, in most cases, only divalent metal ions were investigated and at only one or a few concentrations (Fischer \& Amrhein, 1974; Fujimoto et al., 1974). In this investigation, a range of metal ion concentrations was used. Although $\mathrm{Cu}^{2+}$ (Okabayashi \& Ide, 1970a) and $\mathrm{Ca}^{2+}$ (Song \& Cheung, 1971) inhibit phosphodiesterase activity in most tissues, both metal ions stimulated phosphodiesterase activity in $M$. smegmatis when tested at the appropriate concentration. All the ions tested produced appreciable stimulation of enzyme activity at appropriate concentrations.

The stimulatory effect of $\mathrm{NH}_{4}{ }^{+}$has been reported in dog heart (Nair, 1966). Drummond \& Perrott-Yee (1961) found that the brain enzyme required $\mathrm{Mg}^{2+}$ but that partial activity was obtained in the presence of $\mathrm{Co}^{2+}$ and $\mathrm{Mn}^{2+}$. The enzymes from C. reinharaiii (Fischer \& Amrhein, 1974) and S. carlsbergensis (Speziali \& van Wijk, 1971) were stimulated by $\mathrm{Mn}^{2+}$ at the appropriate concentration. Stimulatory effects of $\mathrm{Co}^{2+}$ (Drummond \& PerrottYee, 1961 ; Cheung 1971), $\mathrm{Ba}^{2+}$ (Okabayashi \& Ide, 1970a) and $\mathrm{Ca}^{2+}$ (Okabayashi \& Ide, $1970 a$; Fischer \& Amrhein, 1974) have also been reported in several tissues.

Pyrophosphate and inorganic phosphate were slightly stimulatory to the $M$. smegmatis enzyme. The enzymes from $S$. carlsbergensis (Speziali \& van Wijk, 1971) and C. reinhardii (Fischer \& Amrhein, 1974) were inhibited by pyrophosphate, but in Serratia marcescens (Okabayashi \& Ide, 1970a) and S. cerevisiae (Fujimoto et al., 1974) pyrophosphate (10 mM) did not affect the enzymes.

The methylxanthines are inhibitors of mammalian phosphodiesterase (Butcher \& Sutherland, 1962) and have been of considerable use in studying the role of cyclic AMP in hormone action. Inhibition by methylxanthines varies among micro-organisms. The enzymes from Dictyostelium discoideum (Chang, 1968) and E. coli (Nielsen, Monard \& Rickenberg, 1973) were apparently not affected by these compounds although Aboud \& Burger (1971) have reported that the E. coli enzyme was inhibited by methylxanthines. The enzymes from Serratia marcescens (Okabayashi \& Ide, 1970a), S. cerevisiae (Fujimoto et al., 1974) and C. reinhardii (Fischer \& Amrhein, 1974) were inhibited by theophylline.

I thank Professor J. G. T. Sneyd of the Department of Clinical Biochemistry, University of Otago, Medical School, Dunedin, New Zealand, for his excellent guidance during the course of this work.

\section{REFERENCES}

Aboud, M. \& Burger, M. (1971). Cyclic $3^{\prime}: 5^{\prime}$ adenosine monophosphate-phosphodiesterase and the release of catabolite repression of $\beta$-galactosidase by exogenous cyclic $3^{\prime}: 5^{\prime}$-adenosine monophosphate in Escherichia coli. Biochemical and Biophysical Research Communications 43, 174-182.

Butcher, R. W. \& Sutherland, E. W. (1962). Adenosine-3': $5^{\prime}$-phosphate in biological materials. Journal of Biological Chemistry 237, 1244-1250.

Chang, Y. Y. (1968). Cyclic 3':5'-adenosine monophosphate phosphodiesterase produced by the slime mold Dictyostelium discoideum. Science 161, 57-59.

Cheung, W. Y. (1971). Cyclic $3^{\prime}: 5^{\prime}$-nucleotide phosphodiesterase. Effect of divalent cations. Biochimica et biophysica acta 242, 395-409.

ClARK, D. G. S. (1971). Intermediary metabolism in Mycobacterium smegmatis. Ph.D. thesis, University of Otago, New Zealand.

DAvID, H. L. (1977). Alkaline phosphatases from Mycobacterium smegmatis. Journal of General Microbiology 101, 99-102.

Drummond, G. I. \& Perrott-Yee, S. (1961).
Enzymatic hydrolysis of adenosine- $3^{\prime}: 5^{\prime}$-phosphoric acid. Journal of Biological Chemistry 236, 1126-1129.

FISCHER, U. \& AMrhein, N. (1974). Cyclic nucleotide phosphodiesterase of Chlamydomonas reinhardtii. Biochimica et biophysica acta 341, 412420.

Fujimoto, M., Ichikawa, A. \& Tomita, K. (1974). Purification and properties of adenosine- $3^{\prime}: 5^{\prime}$. monophosphate phosphodiesterase from baker's yeast. Archives of Biochemistry and Biophysics 161, 54-63.

Loten, E. G. \& SNeyd, J. G. T. (1970). An effect of insulin on adipose-tissue adenosine- $3^{\prime}: 5^{\prime}$ cyclic monophosphate phosphodiesterase. Biochemical Journal 120, 187-193.

Lowry, O. H., Rosebrough, N. J., Farr, A. L. \& Randall, R. J. (1951). Protein measurement with the Folin phenol reagent. Journal of Biological Chemistry 193, 265-275.

NAIR, K. G. (1966). Purification and properties of $3^{\prime}: 5^{\prime}$-cyclic nucleotide phosphodiesterase from dog heart. Biochemistry 5, 150-157. 
Nielsen, L. D., Monard, D. \& RickenberG, H. V. (1973). Cyclic 3':5'-adenosine monophosphate phosphodiesterase of Escherichia coli. Journal of Bacteriology 116, 857-866.

Okabayashi, T. \& Ide, M. (1970a). Cyclic 3':5'nucleotide phosphodiesterase of Serratia marcescens. Biochimica et biophysica acta 220, 116123.

OKabayashi, T. \& IDE, M. (1970 $b)$. Effect of dipicolinic acid on bacterial cyclic $3^{\prime}: 5^{\prime}$-nucleotide phosphodiesterase. Biochimica et biophysica acta 220, 124-126.

Robison, G. A., Butcher, R. W. \& Sutherland, E. W. (1971). Formation and metabolism of cyclic
AMP. In Cyclic AMP, pp. 84-90. Edited by G. A. Robison, R. W. Butcher \& E. W. Sutherland. New York: Academic Press.

Song, S. Y. \& Cheung, W. Y. (1971). Cyclic 3':5'nucleotide phosphodiesterase. Properties of the enzyme of human blood platelets. Biochimica et biophysica acta 242, 593-605.

Speziali, G. A. G. \& van Wijk, R. (1971). Cyclic 3':5'-AMP phosphodiesterase of Saccharomyces carlsbergensis. Inhibition by adenosine 5 '-triphosphate, inorganic pyrophosphate and inorganic polyphosphate. Biochimica et biophysica acta $\mathbf{2 3 5}$, 466-472. 